STATE OF ALASKA

\title{
TIEKEL PROSPECT
}

\section{VALDEZ QUADRANGLE}

by

Cleland N. Conwell

Mining Engineer

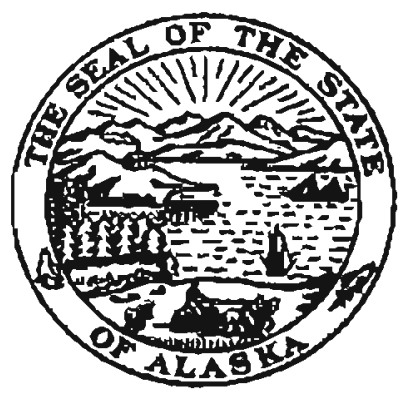

PROSPECT EXAMINATION 86-14 
TABLE OF CONTENTS

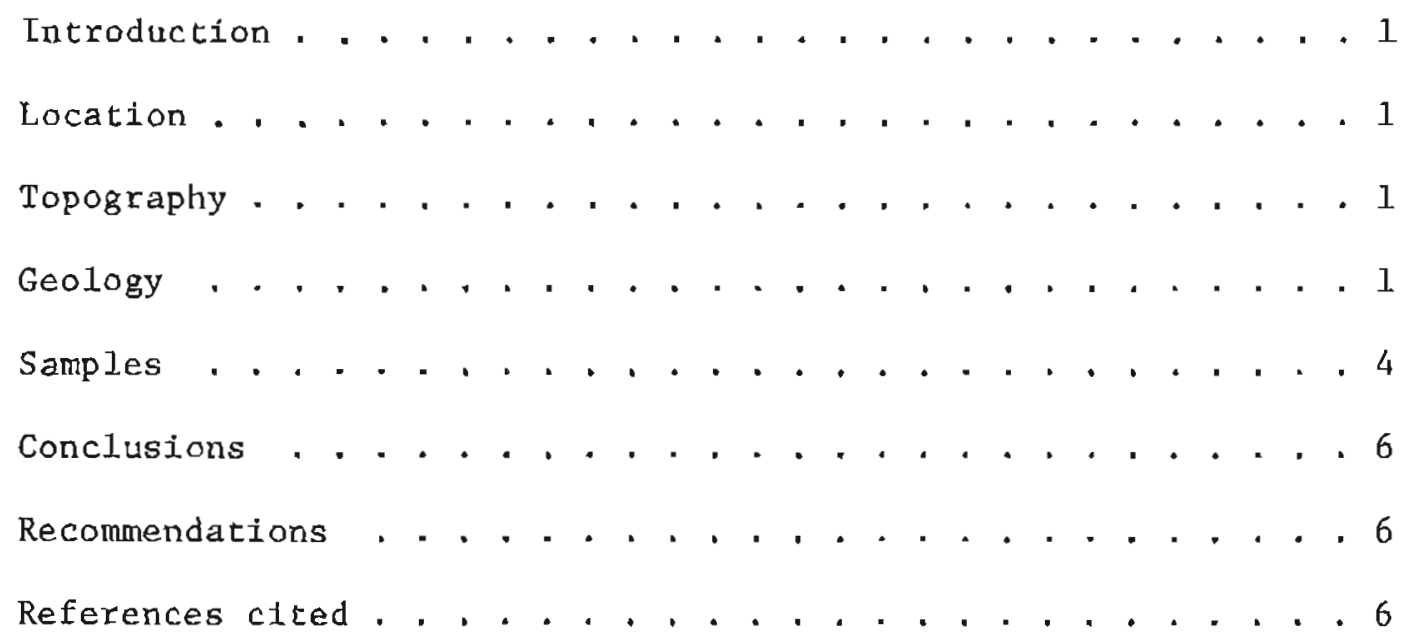

FIGURES

1 Locations Map . . . . . . . . . . . . . . . . . . 2

2 Tiekel Prospect. . . . . . . . . . . . . . . . . 3

TABLES

1 Laboratory Analysis Report . . . . . . . . . . . . . 5 


\section{INTRODUCTION}

On September 30, 1972, I examined a group of claims owned by William H. Buck, P. O. Box 286, Glenallen, Alaska. The examination consisted of mapping the outcrop at a scale of $1^{\prime \prime}=10$ feet and taking 16 samples. The first three samples were used to ddentify rock types and the rest analyzed for metal content.

\section{LOCATION}

The claims are located on the east slde of the Tiekel RIver near Mllepost 52 on the Richardson Highway. The Richardson Highway starts at Valdez, Alaska and goes to Fairbanks. The claims are approximately 52 miles northeast of Valdez, 65 miles south of Glenallen, and about $1 / 4$ mile east of the highway. Figure 1 shows approximate location of the prospect on a portion of the Valdez B-4 quadrangle sheet.

\section{TOPOGRAPHY}

The prospect is located in the very rugged mountains that are part of the Chugach coastal range bordering the Gulf of Alaska. Part of the waters here flow south into Prince William Sound and other streams flow east into the Copper River. The Tiekel River is a tributary of the Copper River.

\section{GEOLOGY}

The oldest rocks in the district include argillite, graywacke, quartzite, banded arg111tte and quartzite with limestone. The sediments are interbedded with flows and tuffs and have been intruded by granitic rocks, chiefly grantte or quartz diorite. All sedimentary rocks have been metamorphosed to some degree. The older rocks are believed to be of early Carbontferous (Mississipplan) age. In the southern part of the Valdez quadrangle there 18 a great thickness of slate and graywacke beds which are folded, contain quartz velns, and have been 1ntruded by sills and dikes of granite-to-quartz diorite composition. These sedimentary rocks are believed to be of Mesozoic age, posstbly Triassic or Late Cretaceous.

The oldest and predominant rock in the immediate area of the prospect is a chlorite-quartz schist. However, 1 t is belleved to be the same rock described by Moffit (1935) as the slate-graywacke series of Mesozoic age. The schist has been intruded by the sulphide-bearing quartz vein. The quartz vein has been offset by faulting and subsequent intrusion of a younger granitic type rock (fig. 2). The predominant minerals are quartz and plagioclase feldspar. The rock is classified as a quartz diorite.

In the area west of the highway there were several small high grade gold mines. Moffit (1935, p. 26) noted: "Furthermore, past experience would indicate that the Mesozoic slate-graywacke rocks give greater promise of yielding gold than older Carboniferous(?) rocks, though why this should be so is not evident.", and "In all the localities where gold is known the slate and graywacke of that vicinity are cut by dikes and sills of quartz diorite porphyry or granite."

Figure 2 shows the location of the quartz vein, schist and quartz diorite. The pattern therefore would fit the general pattern of gold bearing quartz veins in the district. The approximate location of other known prospects within a six mile radius of the property is shown on Figure 1. 


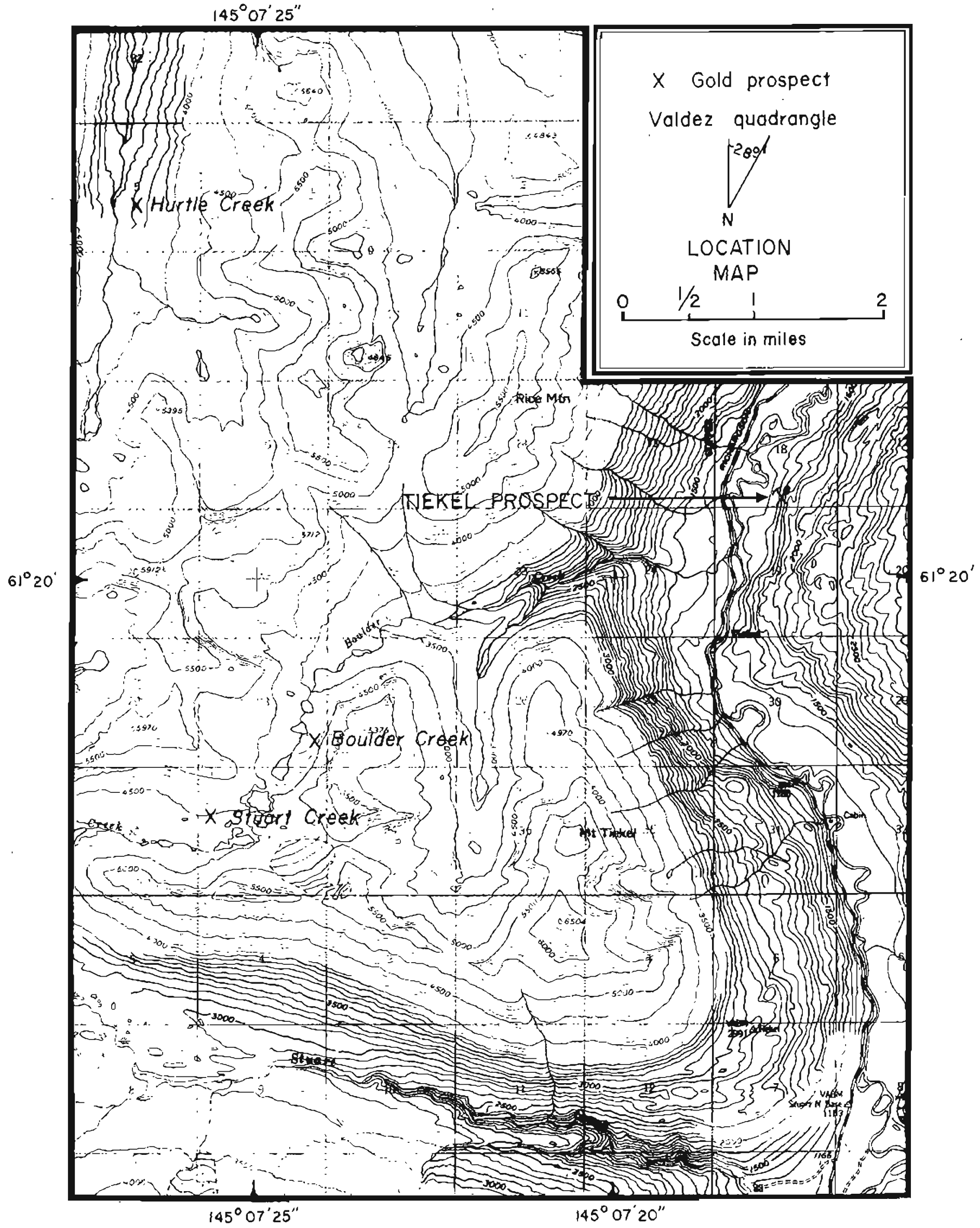




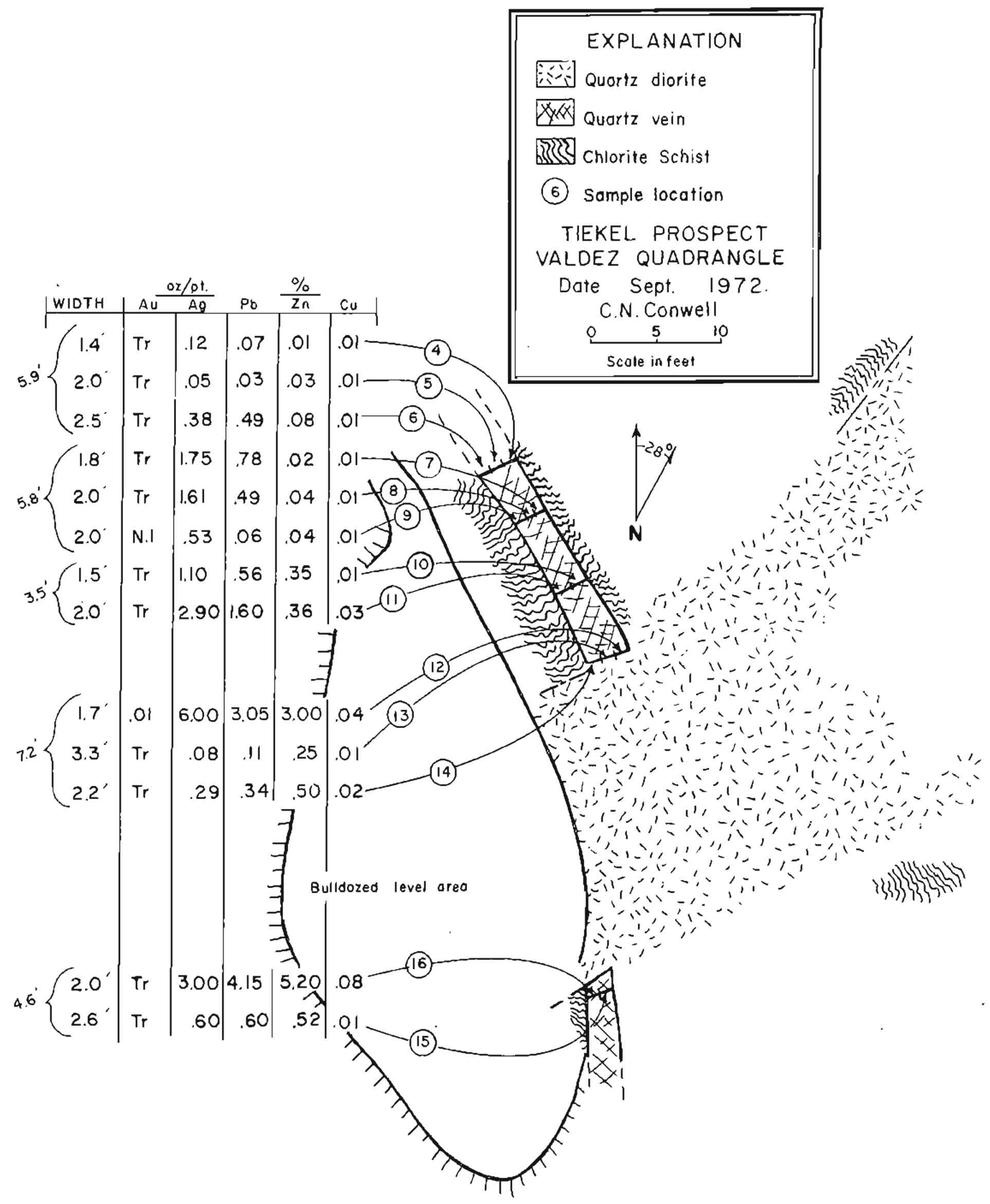

Figure 2 


\section{SAMPLES}

Sample No. 1 was taken of the principal rock type. The mineral assemblage of this rock, determined from a thin section analysis and X-ray diffraction, are chlorite and quartz. Samples 2 and 3 were taken of the quartz-diorite. The principal minerals were determined from thin section analysis to be quartz and plagioclase feldspar. An X-ray diffraction pattern also confirmed the presence of quartz and the plagioclase feldspars. The X-ray mineral identffications were made by Carol 2danovec, of the Alaska Division of Geological and Geophysical Surveys, Fairbanks, Alaska.

The vein was sampled in 4 places with channels cut to extract about 5 pounds of rock per lineal foot. All samples were assayed by Donald Stein, assayer, Alaska Diviston of Geological and Geophysical Surveys, Pairbanks, Alaska. The location of the samples, width and assay values to 2 decimal places are shown on Figure 2 . Table 1 is the assay report.

The sulphide minerals occur as massive pods within the quartz vein. The predominant color of the sulphides is black. The galena (lead sulphide) is easily recognized by color and cleavage. Sphalerfte (zinc sulphide) is recognizable in the hand specimen. However, the assays indlcate low lead and silver values. Therefore a $100 \mathrm{gram}$ split of the best sample was taken for a heavy media separation. The heavy fraction was analyzed by Carol Zdanovec. The major heavy mitreral is arsenopyrite. The minerals as determined by X-ray diffraction are, in order of abundance, quartz, arsenopyrtte, galena and sphalerite. No silver or copper minerals were determined by the X-ray patterns. The fractions with chemical assays are listed below.

\section{ASSAY}

$\begin{array}{ll}\text { Fraction } & \text { Weight } \\ & \text { in Gram }\end{array}$
Weight Per Cent

$\underline{\text { Gold }} \underline{\text { Stlver }} \quad \underline{\text { Copper }} \underline{\text { Lead }} \underline{\text { Zinc }}$

Heavy

Intermediate

Light
14.0

0.042

37.6

0.028

48.4
20.0

8.0

1.91
0.045

0.045

0.015
0.915

5.0

2.0

4.9

0.950 
DM- 11

Rev. 10/67

Report No.

2983

STATE OF ALASKA

Deportment of Natural Resources

Dote of Report

$1 / 17 / 72$

DIVISION OF MINES AND GEOLOGY

Box C, College. Alosko 99701

\section{LABORATORY ANALYSIS REPORT}

For Cle Conwell
Address Wiv of Goologi-sal Sufvay - College
13

A. X-roy flourescence quant. $\square$ semi-quant.

B. X-ray diffroction $\square$

C. Spectrographic quant. $\square$ semi-quant.

$\begin{array}{ll}\text { see below) } & \text { C. Spectrographic } \\ & \text { D. Spectroscopic } \square\end{array}$

\begin{tabular}{|c|c|c|c|c|c|c|}
\hline \multirow[t]{3}{*}{$\begin{array}{l}\text { LABORATORY } \\
\text { NUMBER }\end{array}$} & \multirow[t]{3}{*}{$\begin{array}{l}\text { SAMPLE } \\
\text { MARKED }\end{array}$} & \multicolumn{5}{|c|}{ ANALYSIS OR IDENTIFICATION } \\
\hline & & \multicolumn{2}{|c|}{ Ounces Per Ton } & \multicolumn{3}{|c|}{ - Weight Per Cent } \\
\hline & & Gold & Silver & Copper & Load & Zinc \\
\hline 40904 & 129 & Trace & 0.115 & 0.006 & $0.07 !$ & 0.008 \\
\hline 40905 & 130 & 0.002 & 0.045 & 0.011 & 0.028 & 0.025 \\
\hline 40906 & 131 & 0.006 & 0.38 & 0.007 & 0.485 & 0.075 \\
\hline 40907 & 132 & 0.005 & 1.75 & 0.014 & 0.780 & 0.018 \\
\hline 40908 & 133 & 0.003 & 1.61 & 0.009 & 0.490 & 0.035 \\
\hline 40909 & 134 & $\mathrm{Nil}$ & 0.053 & 0.008 & 0.055 & 0.035 \\
\hline 40910 & 135 & 0.002 & 1.10 & 0.013 & 0.560 & 0.350 \\
\hline 40911 & 136 & 0.006 & 2.9 & 0.025 & 1.60 & 0.360 \\
\hline 40912 & 137 & 0.012 & 6.0 & 0.037 & 3.05 & 3.00 \\
\hline 40913 & 130 & 0.001 & 0.080 & 0.014 & 0.110 & 0.250 \\
\hline 40914 & 139 & $\mathrm{Nil}$ & 0.29 & 0.020 & 0.340 & 0.500 \\
\hline 40915 & 140 & 0.002 & 3.0 & 0.075 & 4.15 & 5.20 \\
\hline 40916 & $14 \mid$ & 0.005 & 0.60 & 0.009 & 0.600 & 0.520 \\
\hline
\end{tabular}

E. Trace of gold means less than 0.01 troy ounces per ton. inil gold means less than 0.001 troy ounces per ton.

Accuracy of the atomic absorption analysis for gold, silver, copper, lead, and zinc is $\pm 10 \%$ of the reported value.
Your samblels) wes ientad for rodio. activity; no sigylificon raditaresivity was detacied.
Date Somple Received $10 / 4 / 70$

E. Aromic absorplion quant. $\square$ semiquant. 团

F. Fire ossoy $\square$

G. Microscopic examination $\square$

H. Other (Specify) $\square$

1. Ultroviolet light

\section{ANALYSIS OR IDENTIFICATION}

E. Weight Per Cent

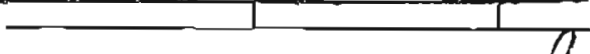
E. Donadd R. Stein ANALYSI \& WORK DON

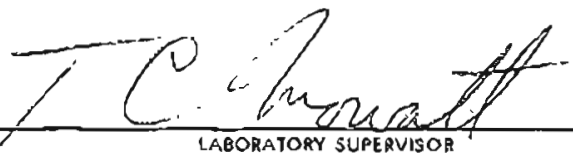

Thomas C. Mlowatt 


\section{CONCLUSIONS}

1. The assay values are too low to consider that the prospect has any immediate economic value.

2. The geologic settlng is similar to that of the high grade gold veins farther west.

\section{RECOMMENDATION}

1. The only add1tional work that seems to be warranted at this time is the possibility of tracing the vein laterally in each dixection from the present exposure. The cuts should be hand dug trenches at approximately 100 feet intervals along the strike. If the vein persists for several hundred feet additional samples should be taken along the strike to determine if there is an increase in the values.

\section{REFERENCES CITED}

Moffit, F. H., Geology of the Tonsina District, Alaska: U, S, Geol. Survey Bu11. $866,1935,38 \mathrm{p}$. 
OM- 11

Rev. $10 / 67$

Report No.

3004

STATE OF ALASKA

Department of Natural Resources

Date of Report Novernoer 27, 1972

DIVISION OF MINES AND GEOLOGY

Box C. College, Alaska 99701

\section{LABORATORY ANALYSIS REPORT}

\section{For \\ Cle conwel}

Number of Somples
Address Div. Of Geological Survey - College
Work Done:
(for Anolysi
A. X-ray flourescence quant. $\square$ semi-quant. $\square$
E. Alomic absorgtion quant. $\square$ semi-quant. $\square$
see below)
B. X-ray diffraction 3
F. Fire assay $\square$
G. Microscopic examination []
C. Spectrogrophic quant. $\square$ semi-quant. $\square$
D. Spectroscopic $\square$
H. Other (Spacify) $\square$
I. Ultroviolet light

Dote Somple Received $11 / 20 / 72$

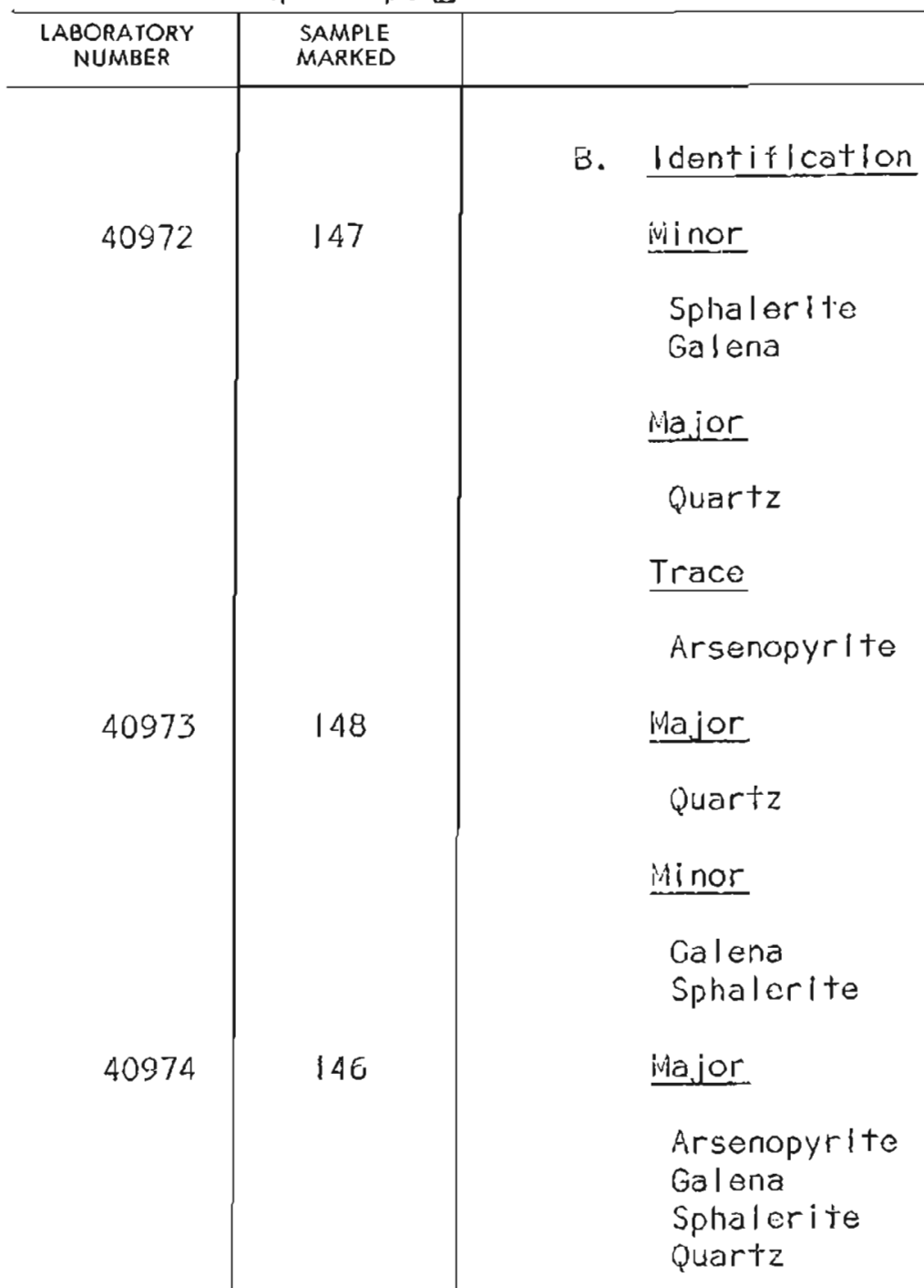


$D M-11$

Rev. $10 / 67$

Report No.

3003

STATE OF ALASKA

Department of Natural Resources

Date of Report

Novernber 24, 1972

DIVISION OF MINES AND GEOLOGY

Bax C. College, Alaska 99701

\section{LABORATORY ANALYSIS REPORT}

For_cle Conwel

Number of Samples
Address Liv. of Geolagical Survey - College

Date Sample Received $1 / / 20 / 72$

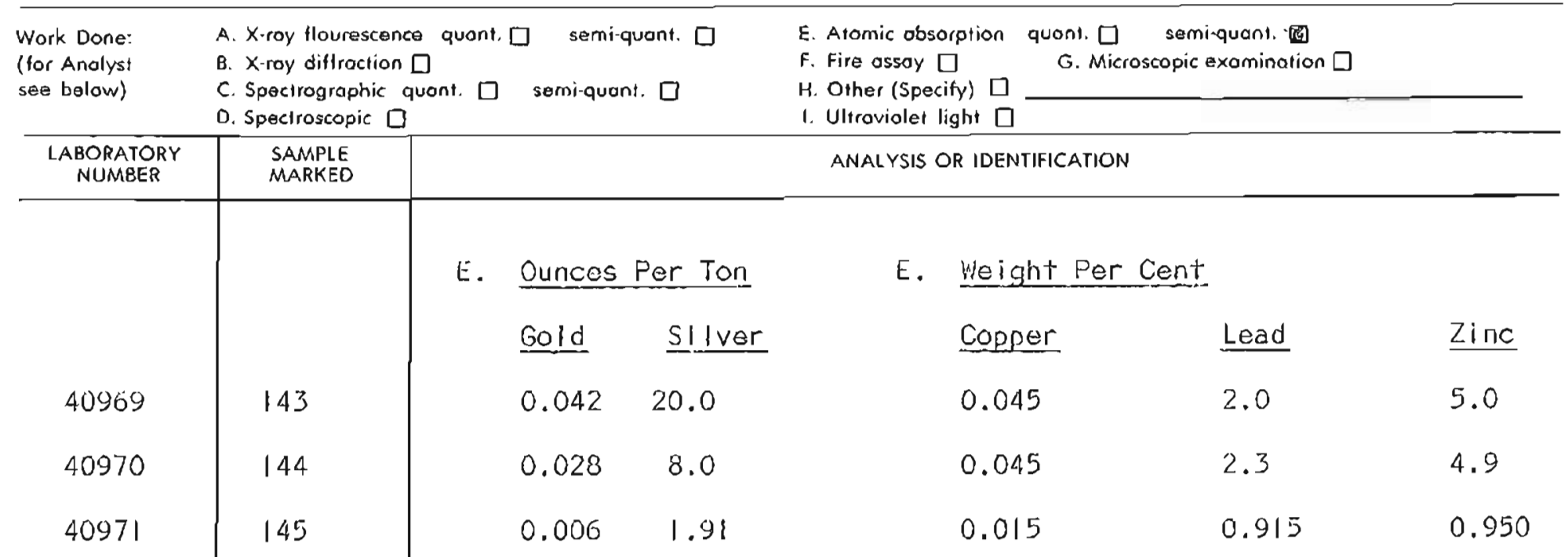

Accuracy of the atomic absorption analysis for gold, silver, copper, lead, and zine is $110 \%$ of the reported value.

E. Donald R. Stein thescedid

ANALYST \& WORX DONE

ANALYST 8 WORK DONE
Your sampictol wos teated for jodio

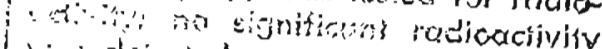

ix... dutiond.

NOTE: Samples discorded ofter 60 days and pulps after 6 monihs unless instructed othenvisa.

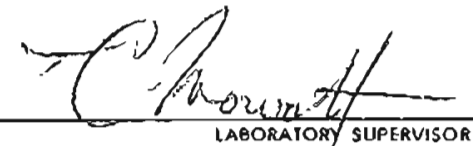

Thomas C. llowatt 

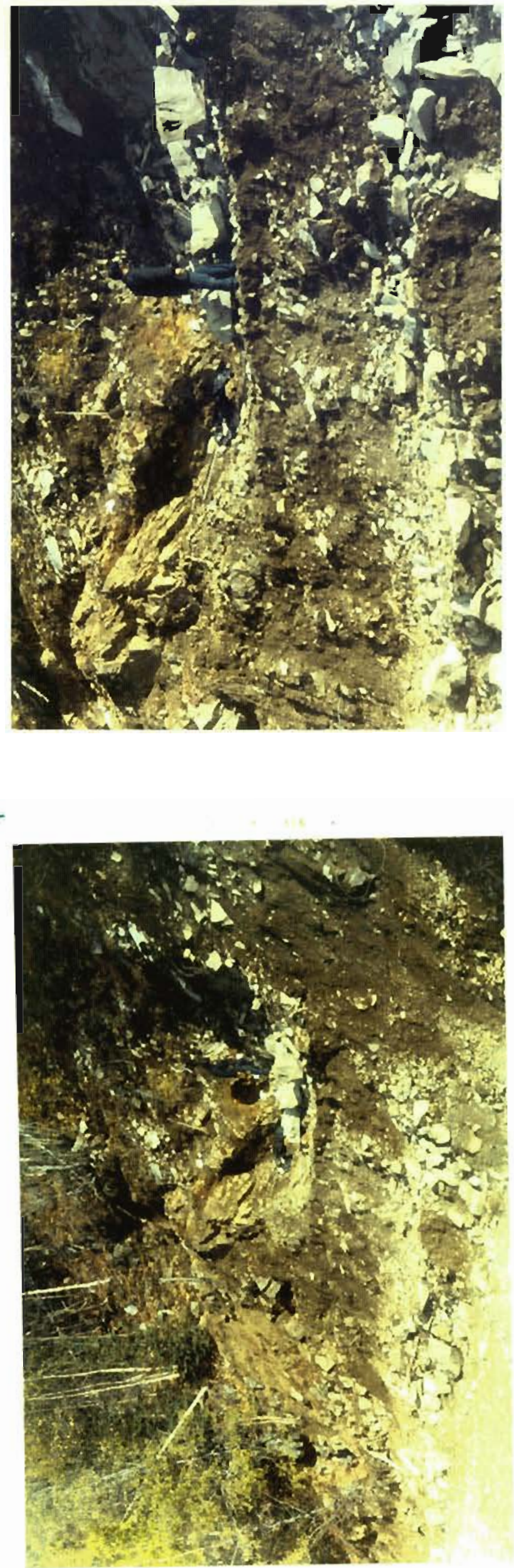
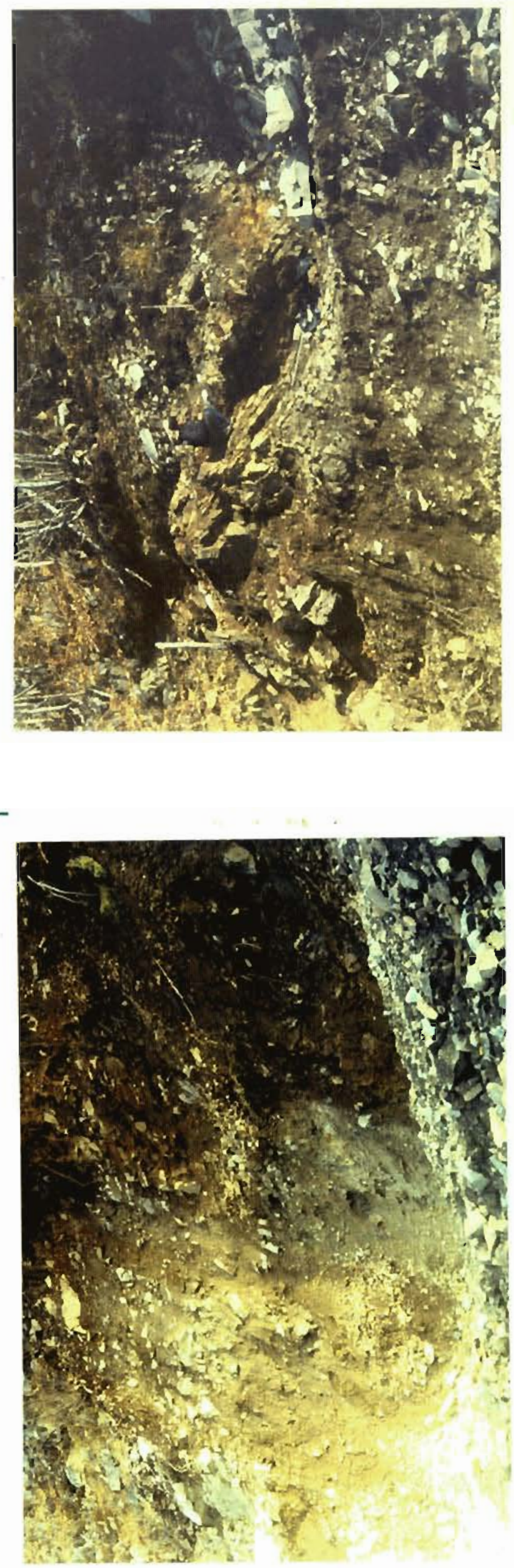